\title{
The fluviatile Bristol Elv Formation, a new Middle Jurassic lithostratigraphic unit from Traill $\varnothing$, North-East Greenland
}

\author{
Jens Therkelsen and Finn Surlyk
}

\begin{abstract}
A new lithostratigraphic unit, the Bristol Elv Formation, is erected in this paper. It is only known from Traill $\varnothing$, East Greenland, where it unconformably overlies Triassic redbeds of the Fleming Fjord Formation and is overlain by lithologically similar shallow marine Upper Bajocian sandstones of the Pelion Formation. The age of the formation is not well constrained but is probably Early Bajocian. The Bristol Elv Formation is at least $155 \mathrm{~m}$ thick and consists of conglomerates, coarse-grained pebbly sandstones and subordinate mudstones, deposited in braided rivers. A finer-grained lacustrine/floodplain unit, c. $37 \mathrm{~m}$ thick, is interbedded with the fluvial sandstones at one locality. Deposition of the fluvio-lacustrine Bristol Elv Formation marks a major change in basin configuration and drainage patterns, reflecting the onset of the important, protracted Middle-Late Jurassic rift event in East Greenland.
\end{abstract}

Keywords: fluvial, lacustrine, Middle Jurassic sediments, new formation, North-East Greenland

J.T., Geological Survey of Denmark and Greenland, Øster Voldgade 10, DK-1350 Copenhagen K, Denmark. Present address: Skude E Jacobsen, Noestvedvej 1, DK-4760 Vordingborg, Denmark. E-mail: JTH@sjas.dk F.S., Geological Institute, University of Copenhagen, Øster Voldgade 10, DK-1350 Copenhagen K, Denmark.

The first detailed description of the Jurassic sandstones on the islands of Traill $\varnothing$ and Geographical Society $\varnothing$ (Fig. 1) was presented by Donovan $(1953,1955,1957)$ who grouped the deposits in the Yellow Series of Maync (1947). Donovan's work was focused on the sediments exposed in the Bjørnedal area in south-eastern Traill $\varnothing$ while the sandstones exposed at Mols Bjerge and Svinhufvud Bjerge received less attention. Donovan (1953, p. 64) suggested that black shales interbedded with sandstones and occasional conglomerates, which he termed the Plant Beds, were deposited in a marine embayment, or possibly on the subaerial part of a debris fan. Higher in the sandstone unit, he found evidence for periodic marine incursions as indicated by occasional ammonite-bearing levels.

A lithostratigraphic scheme covering the Jurassic of Jameson Land in East Greenland was erected by Surlyk et al. (1973) and was extended to the areas north of Kong Oscar Fjord by Surlyk (1977). The Middle Juras- sic sandstones of Traill $\varnothing$ and Geographical Society $\varnothing$ were placed in the Pelion Member of the Vardekløft Formation. This scheme has recently been revised in the light of much new work in the region resulting in rank changes and establishment of new formations and members (see Surlyk 2003, fig. 5).

Fieldwork in the Traill $\varnothing$ area has revealed that sandstones formerly referred exclusively to the shallow marine Pelion Formation (Pelion Member in: Surlyk 1977) actually consist of a lower fluvial unit overlain by marine sandstones (Price \& Whitham 1997; Stemmerik et al. 1997). The fluviatile deposits are placed in a new lithostratigraphic unit, the Bristol Elv Formation, which is erected here as the basal unit of the Middle Jurassic Vardekløft Group on Traill $\varnothing$ (Fig. 2). The new formation consists dominantly of conglomerates, coarse-grained pebbly sandstones and subordinate mudstones and was deposited in a braided river environment, probably in Middle Jurassic, Early Bajo- 


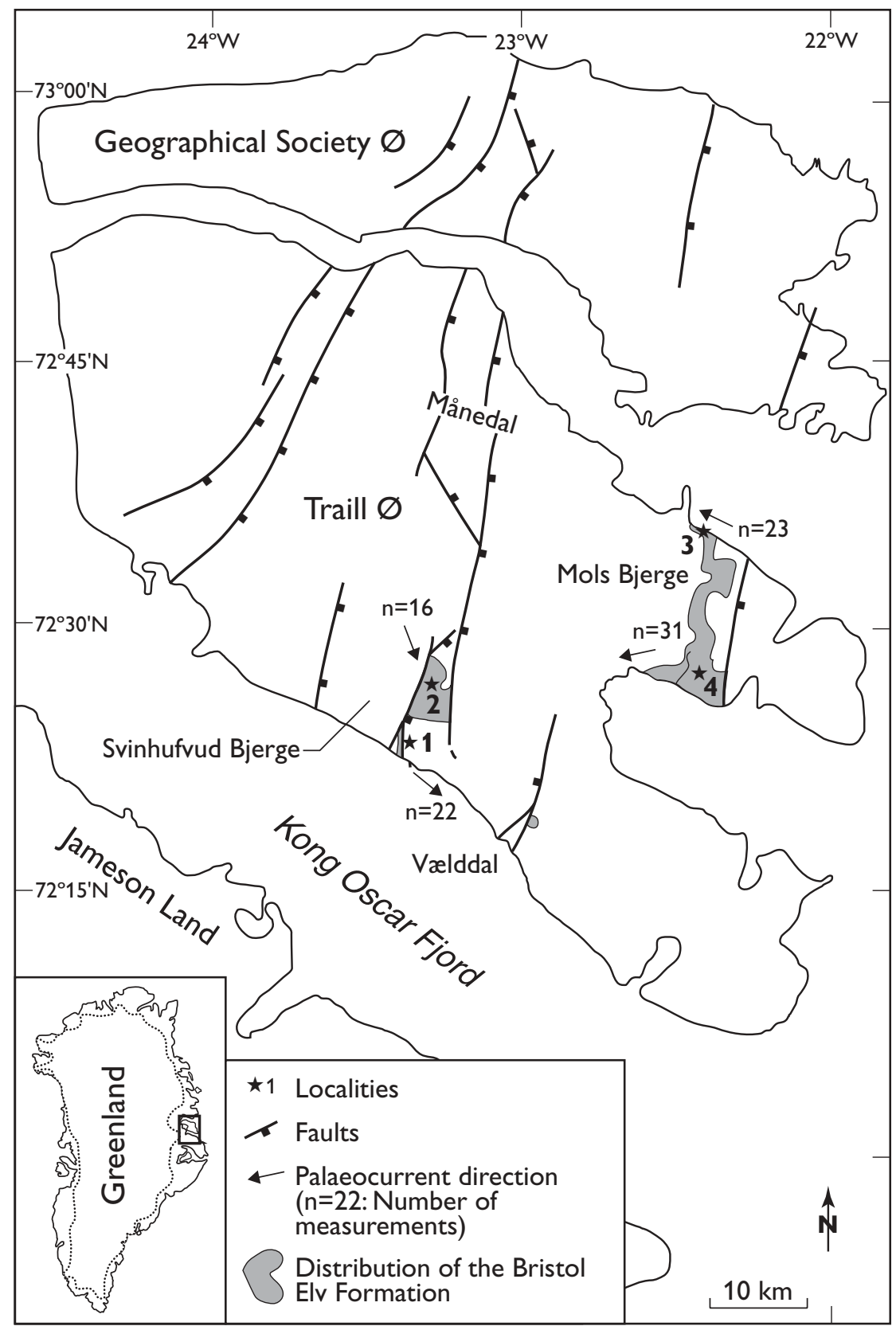

Fig. 1. Map showing the distribution of the Bristol Elv Formation in the Traill $\varnothing$ area, the position of localities and palaeocurrent directions. The map is modified from Stemmerik et al. (1997).

cian time. In one section, fine-grained sandstones, mudstones, medium- to coarse-grained sandstone beds and thin coal seams occur intercalated with the fluvial sandstones, and are interpreted as lacustrine or floodplain deposits.

\section{Bristol Elv Formation}

new formation

History. The strata assigned here to the new Bristol Elv Formation were included in the Yellow Series (Maync 1947) by Donovan (1953) and were referred to the Pelion Member of the Vardekløft Formation by Surlyk (1977). The fluvial nature of the lower part of the succession was recognised independently by Price \& Whitham (1997) and Stemmerik et al. (1997), and labelled PM1 by the former authors. 
Name. After the river Bristol Elv in the southern part of Mols Bjerge, Traill $\varnothing$ (Fig. 1).

Type section. Southern part of Svinhufvud Bjerge (Fig. 1, Locality 1) on the south coast of Traill $\varnothing$ (Figs 1, 3).

Reference sections. North-eastern Svinhufvud Bjerge (Fig. 1, Locality 2), northern and southern Mols Bjerge (Locations 3, 4) and Vælddal, all on Traill $\varnothing$ (Figs 1, 4).

Thickness. The formation is at least $155 \mathrm{~m}$ thick in the southern part of Svinhufvud Bjerge, whereas thicknesses in excess of $80 \mathrm{~m}$ are recorded in northern Mols Bjerge and at Bristol Elv in the southern part of Mols Bjerge. Thicknesses of $280 \mathrm{~m}$ and $520 \mathrm{~m}$ in the southern and northern Svinhufvud Bjerge areas, respectively, and $310 \mathrm{~m}$ in northern Mols Bjerge were stated by Price \& Whitham (1997), but these large values have not been corroborated by our study (Surlyk \& NoeNygaard 2001).

Lithology. The Bristol Elv Formation consists mainly of conglomerates, pebbly sandstones and sandstones in the Mols Bjerge area, whereas more fine-grained deposits are intercalated in the Svinhufvud Bjerge area. The bulk of the formation consists of yellowish to whitish, poorly sorted, coarse-grained sandstones, pebbly sandstones and fine pebble conglomerates with subrounded to well-rounded quartzite pebbles and mudstone intraclasts. Black to dark grey mudstones with centimetre-thick autochthonous coal beds occur intercalated with the sandstones and conglomerates at several levels. The coarse-grained deposits show largescale trough cross-bedding, but the structures are mostly poorly defined. The cross-bedded sets are $0.15-2.0 \mathrm{~m}$ thick, and form cosets up to $7 \mathrm{~m}$ thick. Also observed are large-scale scour-and-fill structures (Fig. 5), planar cross-bedding, planar lamination, rare water escape structures and imprints of tree trunks, which may be found in accumulations. The sediments commonly form fining-upwards units, up to $16 \mathrm{~m}$ thick. On the south coast of Traill $\varnothing$, a sandstone unit, $c .19 \mathrm{~m}$ thick, shows evidence of gently dipping bedforms (Fig. 6, corresponding to the 134-153 m interval in Fig. 3). At Svinhufvud Bjerge, the coarse-grained units are separated by mudstone units up to $6 \mathrm{~m}$ thick, while the coarsegrained units at Mols Bjerge are amalgamated without any fine-grained interbeds.

The mudstones in the Svinhufvud Bjerge area are very uniform in grain size and overlie the sandstones with a sharp boundary. They show a well-developed

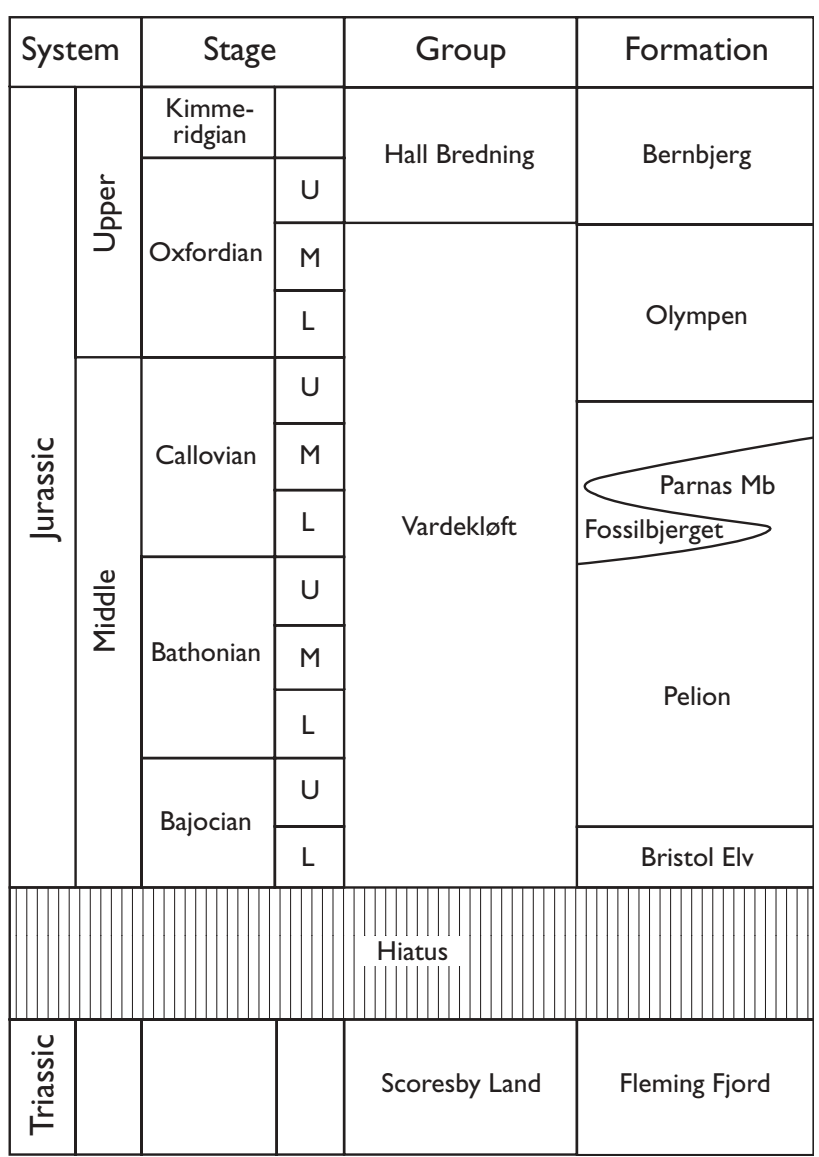

Fig. 2. Lithostratigraphic scheme of the Jurassic succession in the Traill $\varnothing$ area. The age of the Bristol Elv Formation is poorly constrained, but an Early Bajocian age is the most likely. Based on Clemmensen (1980) and D. Strogen (personal communication 2000); see also Surlyk (2003).

to faint lamination, which is commonly disturbed by rooting. A few centimetre-thick layers of mediumgrained sandstone occur in the upper part of the mudstone units at the same level as the rootlets.

The orientation of cross-bed trough axes and foreset azimuths of planar cross-beds in the sandstones at Mols Bjerge generally indicates westerly palaeocurrent directions, whereas the directions in the Svinhufvud Bjerge area are generally towards the south-east. Stylolites are common in the coarse-grained sandstones and fine-grained conglomerates at Mols Bjerge but have not been observed at Svinhufvud Bjerge.

A succession of mainly black to dark grey mudstones and fine-grained sandstones, $c .37 \mathrm{~m}$ thick, with intercalated coal beds and coarse-grained sandstones occurs in the type section at Svinhufvud Bjerge (Fig. 3, $170-207 \mathrm{~m}$ in $\log$ ). The sandstones are trough crossbedded, structureless, cross-laminated or lenticular 


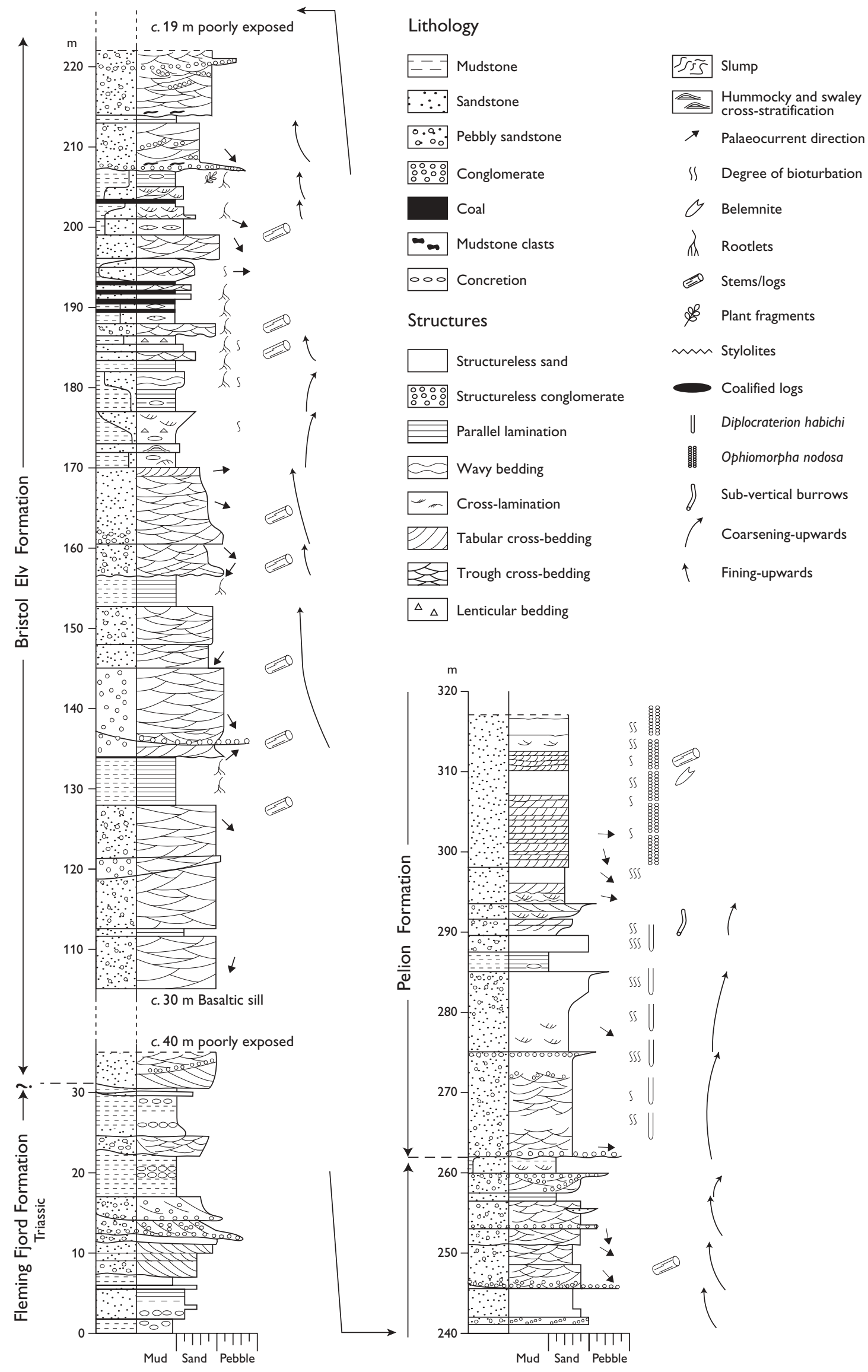


bedded, and display both sheet-like and lenticular geometries. Some of the sandstones show poorly developed wavy surfaces, are weakly bioturbated and contain rare mudstone flasers. The mudstones are mainly laminated or weakly laminated and contain conspicuous root horizons, in situ tree stumps, fern leaves and early diagenetic sideritic concretions. Sandstone beds up to $10 \mathrm{~cm}$ thick with wave ripple crossstratification, similar to micro-hummocky cross-stratification, occur in the mudstones. The ripples have wavelengths up to $30 \mathrm{~cm}$ and heights up to $5 \mathrm{~cm}$. Immediately above one of these sandstone beds, rounded pebbles up to $4 \mathrm{~cm}$ in diameter are present. A sandstone bed, c. $1 \mathrm{~m}$ thick, showing swaley cross-stratification occurs intercalated in the mudstones (Fig. 3, $172-173 \mathrm{~m}$ in log, Fig. 7b).

The wave-rippled and swaley cross-stratified beds form part of two small coarsening-upwards units, $7 \mathrm{~m}$ and $5 \mathrm{~m}$ thick, in the lowest part of the succession (Fig. 3, 170-182 $\mathrm{m}$ in log, Fig. 7a). The lower part of the units consists of laminated and faintly laminated mudstones, which in the lowest unit are intercalated with wave-rippled and swaley cross-stratified sandstone beds. The units grade upwards into very fine-grained sandstones, showing poorly developed wavy surfaces, cross-lamination, lenticular bedding and rare mudstone flasers. Unidentified trace fossils occur in both units and the top beds in the upper coarsening-upwards unit are penetrated by rootlets. Above these two units, coal beds up to $0.45 \mathrm{~m}$ thick and thin mudstone beds occur together with $0.2-2.5 \mathrm{~m}$ thick beds of trough cross-bedded, medium-grained sandstone to fine pebble conglomerate with sharp basal surfaces, showing palaeocurrents towards the east-south-east (Fig. 3, 182$207 \mathrm{~m}$ in $\log$ ). Locally, these beds are overlain by fineto very fine-grained sandstones, forming poorly defined fining-upwards successions.

Pyrite is not present in the coals, but occasionally replaces organic detritus in the sandstones. The coals consist almost entirely of non-detrital vitrinite, which together with the presence of root horizons beneath the coal beds show that they are autochthonous.

Boundaries. The formation unconformably overlies the Upper Triassic Fleming Fjord Formation at Svinhufvud Bjerge and Mols Bjerge as well as in Væelddal

\section{Facing page:}

Fig. 3. Type section (Locality 1) of the Bristol Elv Formation. South Svinhufvud Bjerge, Traill $\varnothing$. Position shown in Fig. 1.
(Clemmensen 1980; D. Strogen, personal communication 2000). The upper boundary is placed at an erosional surface draped by a pebble lag overlain by marine sandstones of the Pelion Formation, which is dominated by medium- to coarse-grained, planar cross-bedded and structureless sandstones with ammonites, belemnites, bivalves and marine trace fossils.

Distribution. The formation is known only from Svinhufvud Bjerge, Mols Bjerge and Vælddal in eastern Traill $\varnothing$ (Fig. 1). The lacustrine/backswamp unit described from the type section is probably correlative to the Plant Beds of Donovan $(1953,1957)$, which occur in Vælddal (Henrik Vosgerau, personal communication 1998).

Geological age. No macrofaunas were found within the Bristol Elv Formation. A few relatively well preserved but as yet unidentified fern leaves were retrieved from a single bed in the lacustrine/floodplain unit in the southern part of Svinhufvud Bjerge. Harris (1946) reported a stem identified as Equisetites sp. A. of inferred Early Jurassic age from Kap Palander in the northernmost Mols Bjerge. Harris (1946) pointed out, however, that this specimen also resembles species of Late Triassic or Middle Jurassic ages, and that it does not give any precise age indication.

Preliminary palynological analysis of samples from the lacustrine/backswamp deposits suggests a broad Late Toarcian - Bathonian age (Karen Dybkjær, personal communication 1998). Age diagnostic palynomorphs include Callialasporites dampieri (late Early Toarcian or younger), Callialasporites turbatus (Late Toarcian or younger), Callialasporites segmentatus (late Early Toarcian or younger) and Foraminisporis jurassicus (Middle Rhaetian - Bajocian) (Batten \& Koppelhus 1996). The Upper Bajocian Cranocephalites borealis Zone is represented in the immediately overlying Pelion Formation sandstones (Donovan 1953, 1957; Callomon 1993; Alsen 1998). This is the lowest Middle Jurassic ammonite zone recognised in East Greenland. In Jameson Land, the Pelion Formation contains a relatively thick marine sandstone unit without ammonites below the lowest occurrence of Cranocephalites borealis. This unit overlies dark mudstones of the Sortehat Formation the top of which is of Early Bajocian age (Underhill \& Partington 1993; Koppelhus \& Hansen 2003). The unit is thought to be a distal marine correlative of the Bristol Elv Formation. This is supported by the stratigraphic position of both units, underlying marine Pelion sandstones of the $C$. borealis Chronozone 
Locality 2

North-eastern

Svinhufvud Bjerge

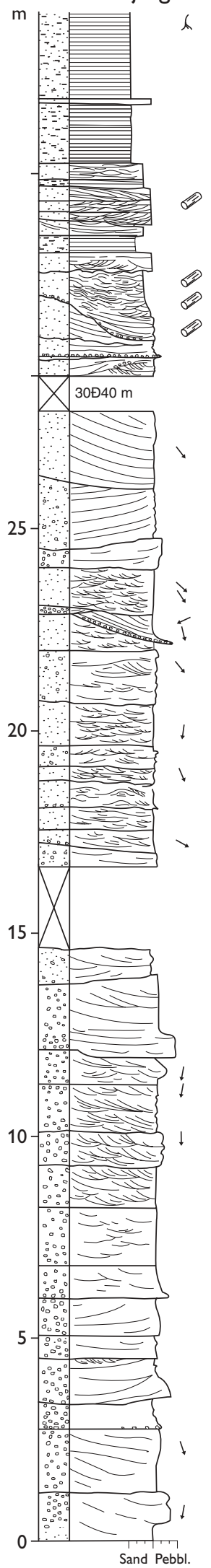

Locality 3

Northern

Mols Bjerge

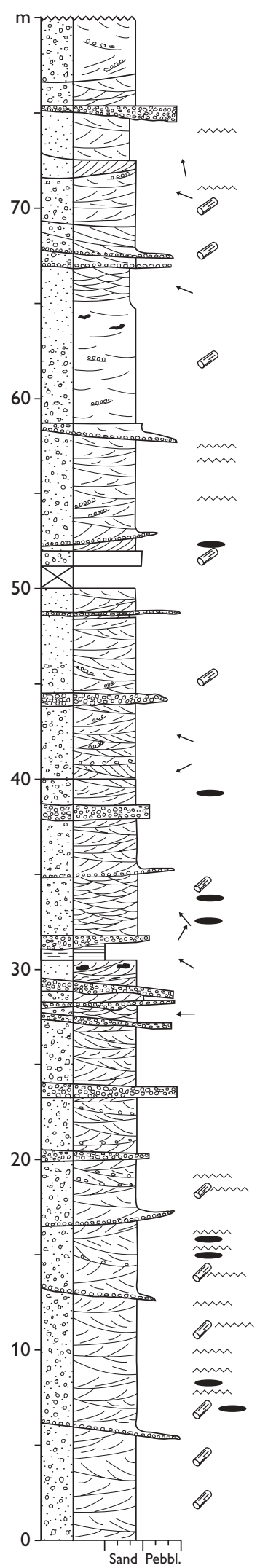

Locality 4

Southern

Mols Bjerge

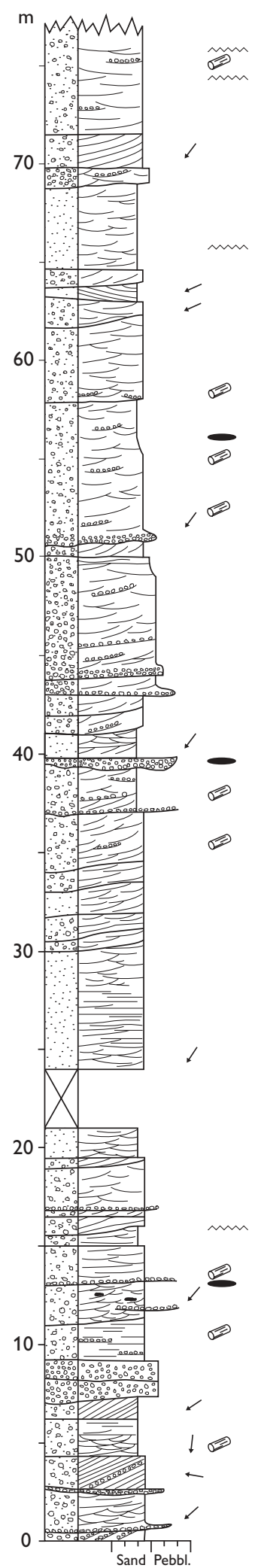




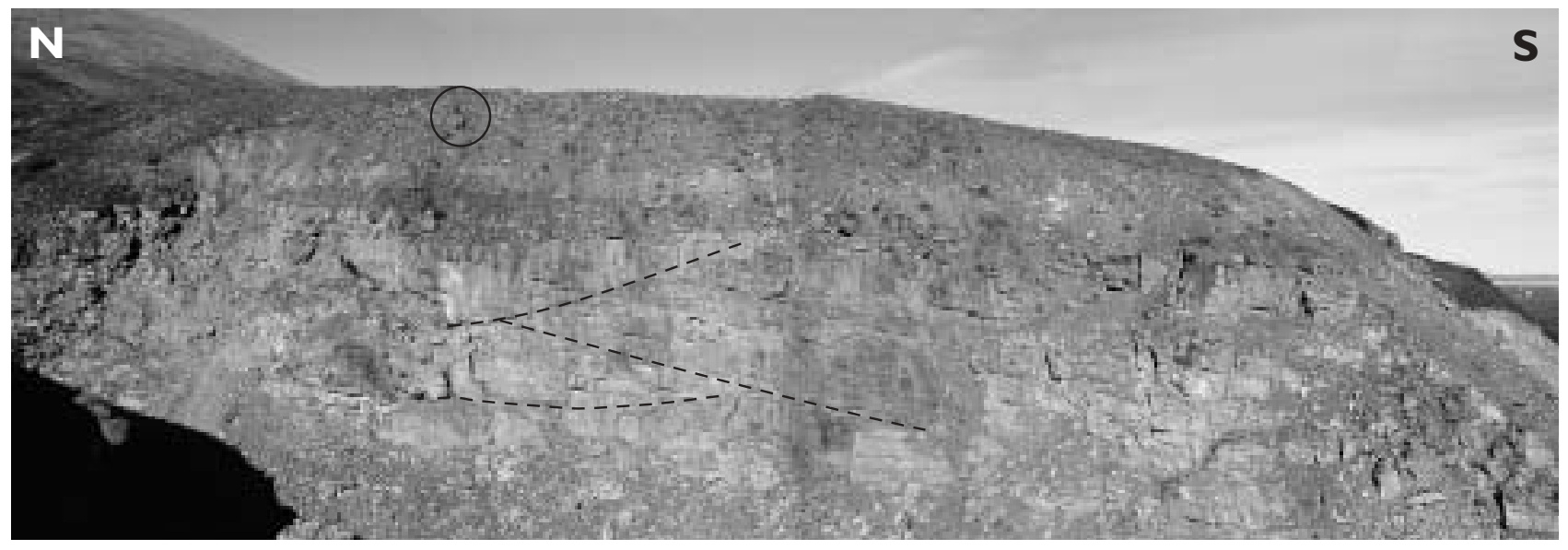

Fig. 5. Coarse-grained sandstone and fine-grained conglomerate with large-scale scour-and-fill structures (indicated by dashed lines below encircled person). Bristol Elv Formation; north-eastern Svinhufvud Bjerge.

and by the marked lithological similarity of the Pelion and Bristol Elv Formations. Lower Jurassic rocks have never been documented outside Jameson Land and all available data thus point towards an Early Bajocian age for the Bristol Elv Formation.

\section{Depositional environment}

The coarse-grain size, the presence of fining-upwards units and trough cross-bedding, the unidirectional palaeocurrents towards the west (in Mols Bjerge) and south-east (in Svinhufvud Bjerge) and the abundance of mudstone intraclasts, the absence of dinoflagellate cysts and marine body and trace fossils indicate that the main part of the Bristol Elv Formation was deposited in a high-energy fluvial environment. Studied samples all show very low total sulphur (TS) contents (max. $0.43 \%$ ) and high $\mathrm{C} / \mathrm{S}$ values (> 10). These data support the interpretation of a terrestrial environment of deposition (Berner \& Raiswell 1984).

In the Svinhufvud Bjerge area, one sandstone unit, approximately $20 \mathrm{~m}$ thick, shows macroforms interpreted as downstream or lateral accretion structures such as epsilon cross-bedding (Allen 1963; Fig. 6). The lower $c .13 \mathrm{~m}$ of this unit displays a fining-upwards

\section{Facing page:}

Fig. 4. Composite detailed reference section from northeastern Svinhufvud Bjerge (Locality 2) and reference sections from northern and southern Mols Bjerge (Localities 3, 4).

Positions shown in Fig. 1. For legend, see Fig. 3. trend, possibly representing lateral channel migration (Allen 1964, 1965). The depth of the channel corresponds to at least the thickness of the macroform (Leeder 1973). If the interpretation of the macroforms is correct, the channel depths were in the $10-13 \mathrm{~m}$ range.

Fluvial styles and models were categorised in terms of channel sinuosity/braiding, sediment type and characteristic architectural elements by Miall $(1985,1996)$. The depositional features of the Bristol Elv Formation, especially concerning the within-channel element and the relatively large channel depths suggest deposition in the 'perennial deep braided river' type of Miall (1996). Reliable interpretation of a fluvial system cannot, however, be based on vertical sections alone (Miall 1996). Analysis of bounding surfaces, and extent, shape and facies relations of the architectural elements has, however, not been possible in the present case due to the nature of the outcrop.

The interbedded mudstones may, due to the sharp boundary to the underlying coarse sandstones and conglomerates, represent relatively abrupt channel abandonment and subsequent passive in-filling of channels and thus cover a confined area, or they may be more extensive bodies covering the entire floodplain area. The studied exposures do not allow conclusions on the lateral extent of the mudstone units. The finegrained homogeneous nature of the mudstones, however, suggests that the distance to the nearest active fluvial channel must have been relatively large leading to deposition of only the finest grain sizes. The sudden change from very coarse sandstone to homogeneous mudstone also indicates a very abrupt abandon- 


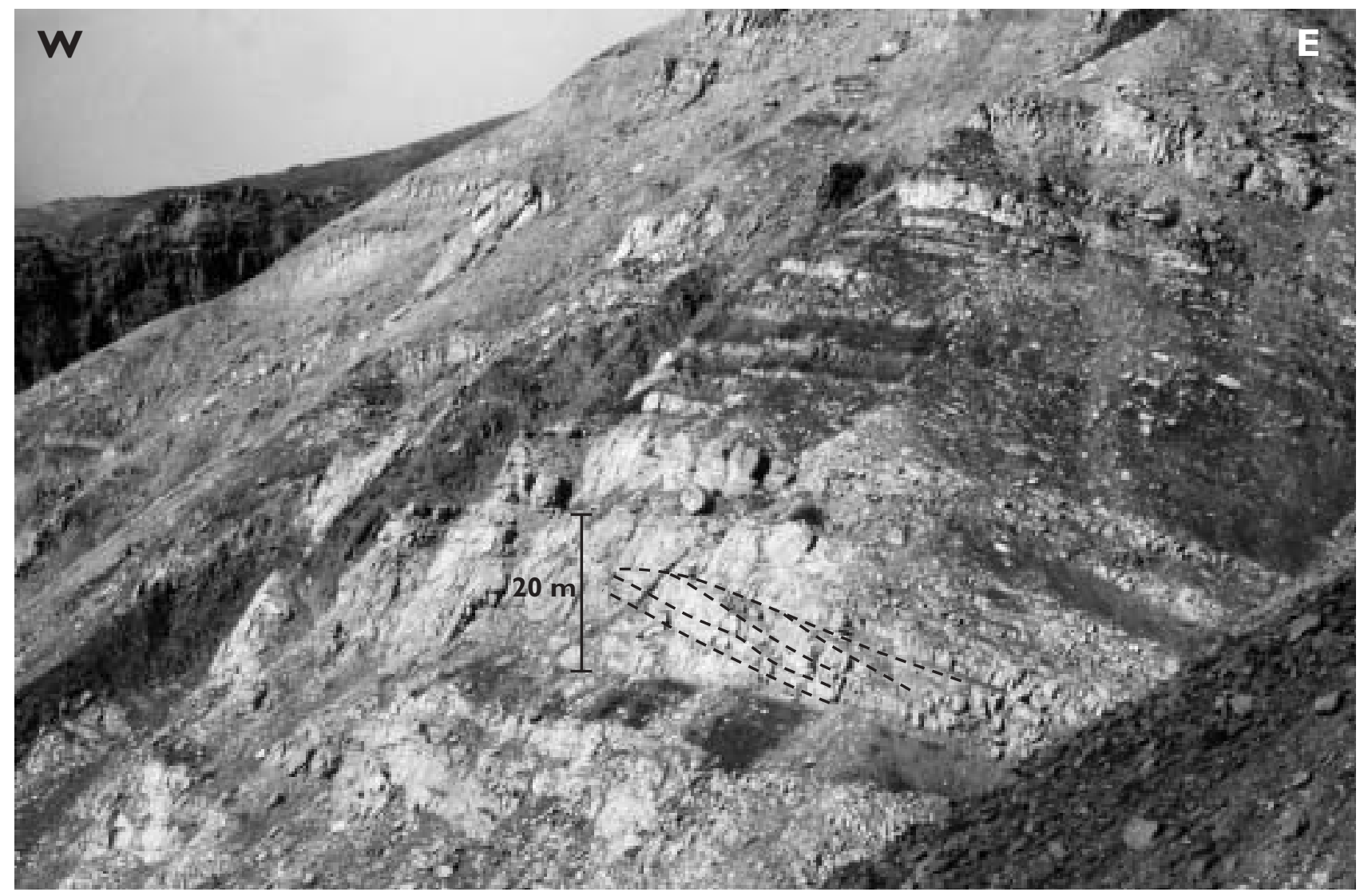

Fig. 6. Fluvial, floodplain and lacustrine deposits on the south coast of Traill $\varnothing$ (Locality 1). Note the $20 \mathrm{~m}$ thick sandstone body in the centre (see Fig. 3, 134-153 m in log) showing down-stream or lateral accretion structures (dashed lines) with bedforms dipping gently to the right (east). The sandstone body overlies dark floodplain mudstones. Type section of the Bristol Elv Formation.

ment of the active channels, which in a relatively short time shifted to a position farther away.

Floodplains in braided river systems are not commonly described in the literature, but studies by Reinfelds \& Nanson (1993) of the Waimakariri River, New Zealand, show that braided rivers, contrary to the common conception, may include large areas of finegrained floodplains. During avulsion events, extensive wetland areas were established and contributed greatly to trapping and deposition of large volumes of finegrained material (e.g. Smith et al. 1989). A similar situation may have occurred at least twice during the lifetime of the Bristol Elv Formation river system, as shown by the occurrence of 3-6 $\mathrm{m}$ thick floodplain mudrocks in the section on the south coast of Traill $\varnothing$ (Figs 1, 6). The presence of root horizons and thin coal beds shows that the floodplain was densely vegetated and developed into peat swamps, before the river channel migrated back over the area and peat formation ceased.

Fine-grained sediment present in the middle part of the type section in Svinhufvud Bjerge is interpreted to have been deposited in a lacustrine/backswamp environment. Fine-grained sandstones intercalated with black and dark grey mudstone in the lower part of this lacustrine/backswamp unit show swaley cross-stratification and wave ripple cross-lamination associated with a pebble lag (Figs 3, 7). Swaley cross-stratification is interpreted as the result of storm-wave deposition above fairweather wave base and has been described from very shallow depths in the large Lake Superior (Greenwood \& Sherman 1986; Sherman \& Greenwood 1989). The wave ripple cross-lamination shows that some vigorous agitation must have occurred, probably during storm events (e.g. Allen 1982). The structures and the associated pebble lag are probably the result of shoreface erosion during storms, and subsequent transport into deeper waters by storm-induced currents (cf. Dam \& Surlyk 1992, 1993). In the uppermost part of the lacustrine succession, the occurrence of a unit that shows coarsening-upwards from mudstone to very fine- 
Fig. 7. Lacustrine deposits from the Bristol Elv Formation, south coast of Traill $\varnothing$ (Locality 1). Length of knife is $21 \mathrm{~cm}$. A: Thin micro-hummocky cross-stratified / wave ripple cross-laminated sandstone intercalated with laminated mudstone. B: Sandstone bed showing swaley crossstratification.
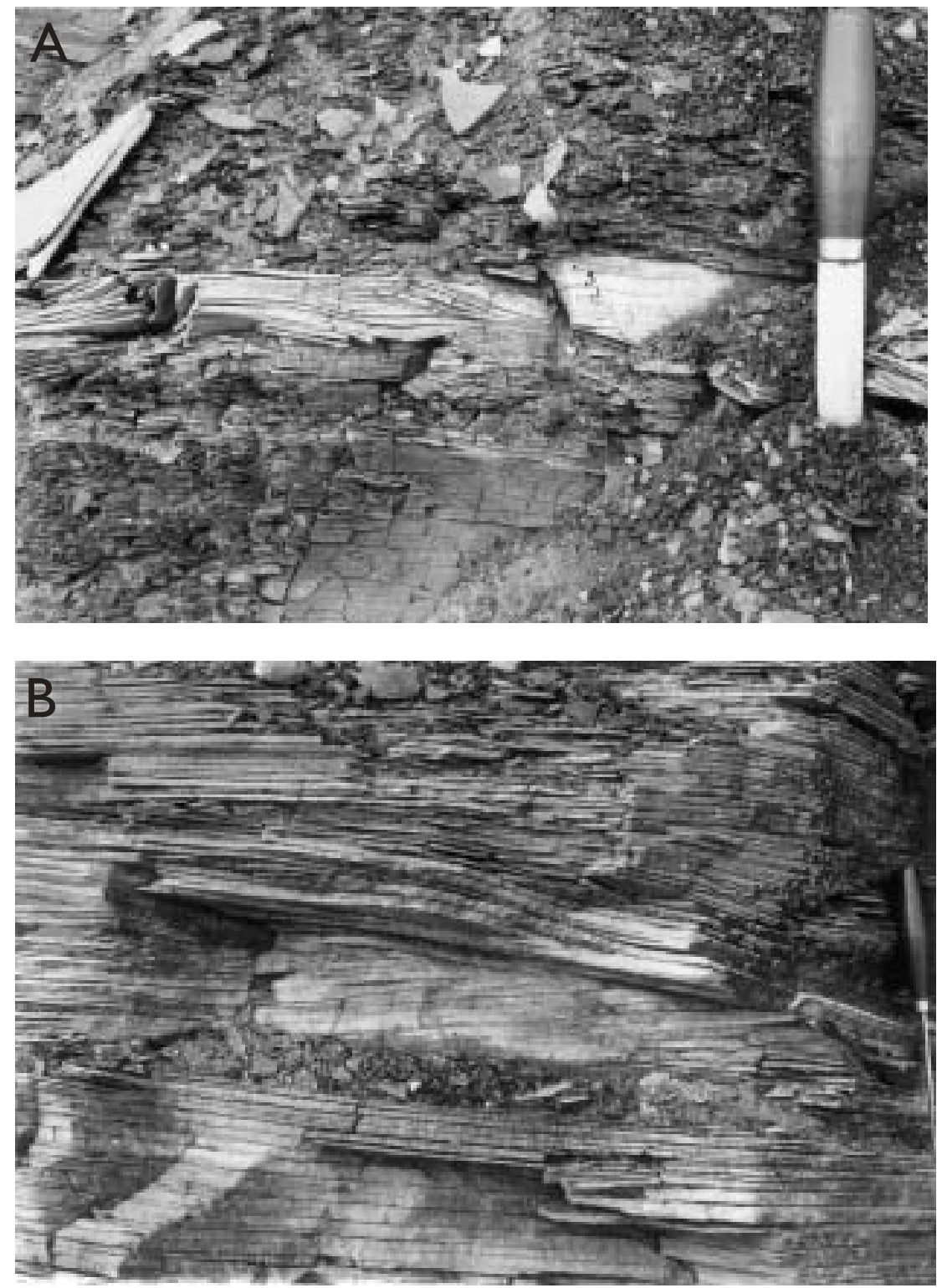

grained sandstone (Fig. 3, 177-182 m) possibly records in-filling of the lake, resulting in lake shoreline progradation and gradual shallowing. The presence of rootlets shows that the lake was sufficiently shallow to allow colonisation of vegetation. Higher in the succession (Fig. 3, 182-207 m), abundant conspicuous root horizons show that vegetation spread across the shores of the lake, which eventually turned into a backswamp environment. The repeated development of autochthonous coal beds in the middle and upper part of the unit suggests that the backswamps were densely vegetated. The $0.2-2.5 \mathrm{~m}$ thick trough cross-bedded sandstone beds associated with the coal beds, probably represent splays into the backswamp from active chan- nels, which were possibly situated north-west of the area. The lack of pyrite in the coal is a good indication of deposition in a freshwater environment (Cohen et al. 1984; Brown \& Cohen 1995; Phillips \& Bustin 1996).

The Plant Beds of Donovan $(1953,1957)$ in Vælddal are interbedded with coarse-grained sandstones and conglomerates dominated by large-scale trough crossbedding, while hummocky and/or swaley cross-stratification, small-scale cross-lamination, root horizons and fossilised leaves occur in the finer grained sediments (Henrik Vosgerau, personal communication 1998). If the Plant Beds of Donovan $(1953,1957)$ are correlatives of the mudstone-dominated part of the Bristol Elv Formation type section in Svinhufvud Bjerge, a system with 
scattered lakes may have existed in the area. The lateral extent of this system must have been at least $20 \mathrm{~km}$.

Gradual in-filling of the lake resulted in development of a wetland area with peat swamps, which was periodically covered by sheet-sands and cut by confined channels where sand was deposited. Thin coarsening-upwards units, which probably represent crevasse splays or deltas, show that active fluvial channels were present in the adjacent area, and the lake system was eventually replaced by a fluvial braided channel system, represented by trough cross-bedded coarse-grained pebbly sandstones. This environment persisted until the area was transgressed by the sea and the shallow marine sandstones of the Pelion Formation were deposited.

\section{Acknowledgements}

This study was undertaken under the auspices of the project 'Resources of the sedimentary basins of North and East Greenland', supported by the Danish Research Council. We thank Karen Dybkjær and Stefan Piasecki for palynological contributions, Jan Andsbjerg, Gregers Dam, and Jon R. Ineson for critical reading of an early manuscript version and reviewers D. Strogen and Michael Larsen for constructive reviews.

\section{References}

Allen, J.R.L. 1963: The classification of cross-stratified units, with notes on their origin. Sedimentology 2, 93-114.

Allen, J.R.L. 1964: Studies in fluviatile sedimentation: six cyclothems from the Lower Old Red Sandstone, Anglo-Welsh basin. Sedimentology 3, 163-198.

Allen, J.R.L. 1965: A review of the origin and characteristics of recent alluvial sediments. Sedimentology 5, 89-191.

Allen, J.R.L. 1982: Sedimentary structures; their character and physical basis. Developments in sedimentology 30A/B, 1266 pp. Amsterdam: Elsevier.

Alsen, P. 1998: Middle Jurassic ammonite biostratigraphy in the Traill $\varnothing$ region, central East Greenland. Abstract. 23rd Nordic Geological Winter Meeting, Aarhus, Denmark (13-16 January), 17 only.

Batten, D.J. \& Koppelhus, E.B. 1996: Biostratigraphic significance of uppermost Triassic and Jurassic miospores in Northwest Europe. In: Jansonius, J. \& McGregor, D.C. (eds): Palynology: principles and applications. American Association of Stratigraphic Palynologists Foundation 2, 795-806.

Berner, R.A. \& Raiswell, R. 1984: C/S method for distinguishing freshwater from marine sedimentary rocks. Geology 12, 365368 .
Brown, K.E. \& Cohen, A.D. 1995: Stratigraphic and micropetrographic occurrences of pyrite in sediments at the confluence of carbonate and peat-forming depositional systems, southern Florida, U.S.A. Organic Geochemistry 22, 105-126.

Callomon, J.H. 1993: The ammonite succession in the Middle Jurassic of East Greenland. Bulletin of the Geological Society of Denmark 40, 83-113.

Clemmensen, L.B. 1980: Triassic lithostratigraphy of East Greenland between Scoresby Sund and Kejser Franz Josephs Fjord. Bulletin Grønlands Geologiske Undersøgelse 139, 56 pp.

Cohen, A.D., Spackman, W. \& Dolsen, P. 1984: Occurrence and distribution of sulfur in peat-forming environments of southern Florida. International Journal of Coal Geology 4, 73-96.

Dam, G. \& Surlyk, F. 1992: Forced regressions in a large waveand storm-dominated anoxic lake, Rhaetian-Sinemurian Kap Stewart Formation, East Greenland. Geology 20, 749-752.

Dam, G. \& Surlyk, F. 1993: Cyclic sedimentation in a large waveand storm-dominated anoxic lake; Kap Stewart Formation (Rhaetian-Sinemurian), Jameson Land, East Greenland. In: Posamentier, H.W. et al. (eds): Sequence stratigraphy and facies associations. International Association of Sedimentologists Special Publication 18, 419-448.

Donovan, D.T. 1953: The Jurassic and Cretaceous stratigraphy and palaeontology of Traill $\varnothing$, East Greenland. Meddelelser om Grønland 111(4), 150 pp.

Donovan, D.T. 1955: The stratigraphy of the Jurassic and Cretaceous rocks of Geographical Society $\varnothing$, East Greenland. Meddelelser om Grønland 103(9), 60 pp.

Donovan, D.T. 1957: The Jurassic and Cretaceous systems in East Greenland. Meddelelser om Grønland 155(4), 214 pp.

Greenwood, B. \& Sherman, D.J. 1986: Hummocky cross-stratification in the surf zone: flow parameters and bedding genesis. Sedimentology 33, 33-46.

Harris, T.M. 1946: Liassic and Rhaetic Plants collected in 193638 from East Greenland. Meddelelser om Grønland 114(9), $39 \mathrm{pp}$.

Koppelhus, E.B. \& Hansen, C.F. 2003: Palynostratigraphy and palaeoenvironment of the Middle Jurassic Sortehat Formation (Neill Klinter Group), Jameson Land, East Greenland. In: Ineson, J.R. \& Surlyk, F. (eds): The Jurassic of Denmark and Greenland. Geological Survey of Denmark and Greenland Bulletin 1, 777-811.

Leeder, M.R. 1973: Fluviatile fining-upwards cycles and the magnitude of palaeochannels. Geological Magazine 110(3), 265-276.

Maync, W. 1947: Stratigraphie der Jurabildungen Ostgrönlands zwischen Hochstetterbugten $\left(75^{\circ} \mathrm{N}\right)$ und dem Kejser Franz Joseph Fjord $\left(73^{\circ} \mathrm{N}\right)$. Meddelelser om Grønland 132(2), 223 pp.

Miall, A.D. 1985: Architectural-element analysis: a new method of facies analysis applied to fluvial deposits. Earth-Science Reviews 22(4), 261-308.

Miall, A.D. 1996: The geology of fluvial deposits: sedimentary facies, basin analysis and petroleum geology, 582 pp. Berlin: Springer-Verlag.

Phillips, S. \& Bustin, R.M. 1996: Sulfur in the Changuinola peat deposit, Panama, as an indicator of the environments of 
deposition of peat and coal. Journal of Sedimentary Research 66(1), 184-196.

Price, S.P. \& Whitham, A.G. 1997: Exhumed hydrocarbon traps in East Greenland: analogs for the Lower-Middle Jurassic play of Northwest Europe. American Association of Petroleum Geologists Bulletin 81(2), 196-221.

Reinfelds, I. \& Nanson, G. 1993: Formation of braided river floodplains, Waimakariri River, New Zealand. Sedimentology 40, 1113-1127.

Sherman, D.J. \& Greenwood, B. 1989: Hummocky cross-stratification and post-vortex ripples: length scales and hydraulic analysis. Sedimentology 36, 981-986.

Smith, N.D., Cross, T.A., Dufficy, J.P. \& Clough, S.R. 1989: Anatomy of an avulsion. Sedimentology 36, 1-24.

Stemmerik, L., Clausen, O.R., Korstgård, J., Larsen, M., Piasecki, S., Seidler, L., Surlyk, F. \& Therkelsen, J. 1997: Petroleum geological investigations in East Greenland: project 'Resources of the sedimentary basins of North and East Greenland'. Geology of Greenland Survey Bulletin 176, 29-38.

Surlyk, F. 1977: Stratigraphy, tectonics and palaeogeography of the Jurassic sediments of the areas north of Kong Oscars Fjord, East Greenland. Bulletin Grønlands Geologiske Undersøgelse 123, 56 pp.
Surlyk, F. 2003: The Jurassic of East Greenland: a sedimentary record of thermal subsidence, onset and culmination of rifting. In: Ineson, J.R. \& Surlyk, F. (eds): The Jurassic of Denmark and Greenland. Geological Survey of Denmark and Greenland Bulletin 1, 659-722.

Surlyk, F. \& Noe-Nygaard, N. 2001: Cretaceous faulting and associated coarse-grained marine gravity flow sedimentation, Traill $\varnothing$, East Greenland. In: Martinsen, O.J. \& Dreyer, T. (eds): Sedimentary environments offshore Norway - Palaeozoic to Recent. Norwegian Petroleum Society (NPF) Special Publication 10, 293-319.

Surlyk, F., Callomon, J.H., Bromley, R.G. \& Birkelund, T. 1973: Stratigraphy of the Jurassic - Lower Cretaceous sediments of Jameson Land and Scoresby Land, East Greenland. Bulletin Grønlands Geologiske Undersøgelse 105, 76 pp.

Underhill, J. \& Partington, M.A. 1993: Use of genetic sequence stratigraphy in defining and determining a regional tectonic control on the 'Mid-Cimmerian Unconformity' - implications for North Sea basin development and the global sea-level chart. In: Weimer, P. \& Posamentier, H.W. (eds): Siliciclastic sequence stratigraphy: recent developments and applications. American Association of Petroleum Geologists Memoir 58, 449-484. 